\title{
Purification and Characterization of Two Aminopeptidases Produced by Brevibacterium linens
}

\author{
By KIYOSHI HAYASHI*† AND BARRY A. LA W \\ AFRC Institute of Food Research, Reading Laboratory, Shinfield, Reading RG2 9AT, UK
}

(Received 28 December 1988; revised 13 March 1989; accepted 22 March 1989)

\begin{abstract}
Two aminopeptidases, designated as aminopeptidase A and B, were purified 1720- and 1950fold, respectively, from the culture filtrate of Brevibacterium linens $\mathrm{F}$ by ammonium sulphate fractionation, a series of column chromatography steps on DEAE-Sephadex, DEAE-Trisacryl $\mathrm{M}$ and Mono-Q, and gel filtration on Superose- 6 . Aminopeptidase A accounted for $85 \%$ of the aminopeptidase activity remaining by the end of purification. The purified enzymes were homogeneous as judged by disc gel electrophoresis. Aminopeptidases A and B showed the same $\mathrm{pH}$ optimum of 9.3 and apparent temperature optimum of $40^{\circ} \mathrm{C}$, although the former showed slightly higher $\mathrm{pH}$ stability than the latter. $\mathrm{NaCl}$ or $\mathrm{KCl}$ concentrations to $2 \mathrm{M}$ did not affect the activities or stabilities of aminopeptidases $\mathrm{A}$ and $\mathrm{B}$. Both enzymes were completely inhibited by incubation with EDTA, indicating that they are metalloenzymes, and were reactivated by incubation with $\mathrm{Ca}^{2+}, \mathrm{Co}^{2+}, \mathrm{Mg}^{2+}, \mathrm{Zn}^{2+}$ or $\mathrm{Mn}^{2+}$. The $M_{\mathrm{r}}$ values of aminopeptidases $\mathrm{A}$ and $\mathrm{B}$ were estimated as 150000 and 110000 , respectively, by gel filtration on Superose-6, and as 36000 and 26000 , respectively, by SDS-PAGE. It was thus assumed that each of the native enzymes exists as a tetramer. The $K_{\mathrm{m}}$ values of aminopeptidase A and B for L-leucine-p-nitroanilide were calculated to be $16 \cdot 1$ and $15.2 \mathrm{mM}$, respectively. The substrate specificities of aminopeptidases $A$ and $B$ were similar to each other.
\end{abstract}

\section{INTRODUCTION}

Brevibacterium linens is an important component of the surface microfiora of smear-ripened cheese varieties (e.g. Danbo, Limburger, Gruyère), where it is involved in the ripening process, in changing the texture of the cheese, and in providing amino acids as substrates for flavourproducing enzymes (e.g. deaminase, demethiolase; Law, 1984).

$B$. linens produces both extracellular proteinase and peptidase activity. The present paper deals largely with the aminopeptidase. Foissy $(1978 a, b, c)$ purified and characterized a single aminopeptidase produced by $B$. linens. However, multiple forms of peptide hydrolase active on Leu-Tyr have been reported from this species (Sørhaug, 1981; Torgersen \& Sørhaug, 1978). For example, Sørhaug (1981) claimed, based on the results of zymograms of crude extracts, that one strain produced five electrophoretically distinct peptide hydrolases active on Leu-Tyr.

In this report, we describe the purification and characterization of two aminopeptidases produced by $B$. linens $\mathrm{F}$. We show that the purified aminopeptidases have a broad specificity which is considered to be appropriate for their role in cheese ripening.

\section{METHODS}

Micro-organisms and culture conditions. Brevibacterium linens F, which was kindly donated by Chr. Hansen's Laboratory Ltd, Wisconsin, USA, was cultivated aerobically on an orbital incubator at a speed of 250 r.p.m. in a medium composed of tryptone $1 \%(\mathrm{w} / \mathrm{v})$, glucose $0.5 \%$, soytone $0.3 \%$, yeast extract $0 \cdot 1 \%, \mathrm{~K}_{2} \mathrm{HPO}_{4} 0 \cdot 25 \%$ and $\mathrm{MgSO}_{4} \cdot 7 \mathrm{H}_{2} \mathrm{O} 0.02 \%, \mathrm{pH} 7 \cdot 0$. After $48 \mathrm{~h}$ of cultivation at $24{ }^{\circ} \mathrm{C}$, the cells were harvested by centrifugation at $5000 \mathrm{~g}$ for $10 \mathrm{~min}$ at $4^{\circ} \mathrm{C}$.

$\dagger$ Present address: National Food Research Institute, Ministry of Agriculture, Forestry and Fisheries, Kannondai, Tsukuba, Ibaraki 305, Japan.

Abbreviations: LNA, L-leucine-p-nitroanilide; $p$-NA, $p$-nitroanilide. 
Measurement of enzyme activities. Proteinase activity was measured at $\mathrm{pH} 9.0$ using casein as a substrate. The enzyme reaction was carried out at $30^{\circ} \mathrm{C}$ for $30 \mathrm{~min}$ and then released peptides were measured by the method of Folin \& Ciocalteu (1927). Aminopeptidase activity was determined in $50 \mathrm{~mm}$-Tris/ $\mathrm{HCl}$ buffer at pH 8.5 at $30^{\circ} \mathrm{C}$ using L-leucine-p-nitroanilide (LNA) (1.74 mM) as a substrate (Foissy, 1978a). Methanol (0.1\%) was included in the assay mixture $(2 \mathrm{ml})$ owing to the low solubility of LNA. One unit of activity is defined as the amount of enzyme which produces $1 \mu \mathrm{mol} p$-nitroaniline $\min ^{-1}$ under the standard condition.

Buffers used to investigate the effects of temperature and $\mathrm{pH}$ on aminopeptidase activity. All buffers were used at a concentration of $50 \mathrm{mM}$. Thermal stability and optimum temperature were measured in Tris/HCl buffer, $\mathrm{pH} \mathrm{8.5.}$ Acetate buffer of pH 5.0-5.8, 1,3-bis[tris(hydroxymethyl)methylamino]propane buffer of pH 5.6-10.0 and 3-(cyclohexylamino)-1-propanesulphonate buffer of $\mathrm{pH} 9.5-11.3$ were used for the measurement of $\mathrm{pH}$ stability. In order to investigate optimum $\mathrm{pH}$, the following additional buffers were used : phosphate buffer, $\mathrm{pH} 6 \cdot 5-8 \cdot 1 ; N-(2-$ hydroxyethyl)piperazine- $\mathrm{N}^{\prime}$-(2-ethanesulphonate) buffer, $\mathrm{pH} \mathrm{6.8-8 \cdot 3;}$ Tris/HCl buffer, $\mathrm{pH} 7 \cdot 0-9 \cdot 0$; glycine buffer, pH 9.0-11.0.

Purification of aminopeptidase. The separations with Mono-Q and Superose-6 (Pharmacia LKB Biotechnology Co.) were carried out at room temperature and all other purification steps at $4{ }^{\circ} \mathrm{C}$.

Solid ammonium sulphate was added to the culture supernatant (10 litres) to a final saturation of $90 \%$. The precipitate was collected by centrifugation at $10000 \mathrm{~g}$ for $30 \mathrm{~min}$ and dissolved in $110 \mathrm{ml} 20 \mathrm{mM}$-phosphate buffer, $\mathrm{pH} 7 \cdot 0$. The solution was dialysed overnight against 10 litres of the same buffer containing $0 \cdot 2 \mathrm{M}-\mathrm{NaCl}$.

Dialysed solution $(120 \mathrm{ml}$ ) containing $3.15 \mathrm{~g}$ protein was applied to a DEAE-Sephadex A-50 (Pharmacia LKB Biotechnology Co. $)$ column $(3.2 \times 27 \mathrm{~cm})$ previously equilibrated with the same buffer containing $0 \cdot 2 \mathrm{M}-\mathrm{NaCl}$. The column was eluted with a linear gradient of $\mathrm{NaCl}$ from 0.2 to $0.8 \mathrm{M}$ in the buffer $(1300 \mathrm{ml})$. Fractions $(12 \mathrm{ml})$ were collected and assayed for proteinase and aminopeptidase activity.

Aminopeptidase fractions were pooled and dialysed against $20 \mathrm{mM}$-Tris/ $\mathrm{HCl}$ buffer (pH 8.0) containing $0 \cdot 15 \mathrm{M}-$ $\mathrm{NaCl}$. The dialysed solution was applied to a column $(1.6 \times 25 \mathrm{~cm})$ containing DEAE-Trisacryl M (Pharmacia LKB Biotechnology Co.) equilibrated with the same buffer containing $0 \cdot 15 \mathrm{M}-\mathrm{NaCl}$. The column was eluted with a linear gradient of $\mathrm{NaCl}$ from 0.15 to $0.5 \mathrm{M}(500 \mathrm{ml})$ and fractions $(6 \mathrm{ml})$ containing aminopeptidase were pooled and stored at $-20^{\circ} \mathrm{C}$.

Part of the fraction (about $0.5 \mathrm{mg}$ protein) was applied to a column of Mono-Q HR5/5 $(0.5 \times 5 \mathrm{~cm})$ equilibrated with $25 \mathrm{~mm}$-piperazine/ $\mathrm{HCl}$ buffer, $\mathrm{pH} 6 \cdot 0$. The column was eluted with a linear gradient of $\mathrm{NaCl}$ in the buffer (40 $\mathrm{ml}$ ) from 0.3 to $0.5 \mathrm{M}$. The active fractions were pooled and concentrated by using a Collodion bag (Sartorius).

A portion of pooled concentrates (about $0.5 \mathrm{mg}$ protein) was loaded on a gel filtration column of Superose-6 HR10/30 $(1 \times 30 \mathrm{~cm})$ previously equilibrated with $20 \mathrm{~mm}$-Tris $/ \mathrm{HCl}$ buffer $(\mathrm{pH} 8.0)$ containing $0 \cdot 3 \mathrm{M}-\mathrm{NaCl}$. The active fractions were pooled and used as purified enzyme fractions of aminopeptidase $A$ and $B$. The last two steps were repeated as required.

Determination of $K_{m}$ and $V_{\max }$. In order to calculate $K_{\mathrm{m}}$ and $V_{\max }$, enzyme activity was measured twice over different concentrations of substrates; Leu-Leu (from 15 to $100 \mathrm{~mm}$ ), Leu-Arg (from 2 to $20 \mathrm{mM}$ ) and LNA (from 0.85 to $3 \mathrm{mM})$. The reaction was initiated by adding enzyme (6.8 milliunits in $40 \mu \mathrm{l})$ to the preincubated substrate solution of $50 \mathrm{~mm}$-Tris $/ \mathrm{HCl}$ buffer, $\mathrm{pH} 8.8(360 \mu \mathrm{l})$. Change of absorbance at $235 \mathrm{~nm}$ (for Leu-Leu), $230 \mathrm{~nm}$ (for Leu-Arg) or $410 \mathrm{~nm}$ (for LNA) was recorded for 5 to $30 \mathrm{~min}$ to calculate the initial rate of hydrolysis at $30^{\circ} \mathrm{C}$.

Substrate specificity. The initial rates of hydrolysis of peptides were measured twice at $30^{\circ} \mathrm{C}$ in borate buffer (pH 9.0) by the modified ninhydrin method (Doi et al., 1981).

Polyacrylamide gel electrophoresis $(P A G E)$. PAGE for aminopeptidase A $(10 \mu \mathrm{g})$ and B $(7 \mu \mathrm{g})$ was performed at pH 8.3 by the method described by Ornstein (1964). Activity staining was performed by laying gels on an agar plate containing $1 \mathrm{mg} \mathrm{LNA} \mathrm{ml}^{-1}$ and $10 \mathrm{~mm}$-Tris/HCl buffer, pH 8.5. SDS-PAGE for aminopeptidase A (20 $\left.\mu \mathrm{g}\right)$ and aminopeptidase B $(14 \mu \mathrm{g})$ was performed in $10 \%(\mathrm{w} / \mathrm{v})$ polyacrylamide disc gels with the phosphate buffer system described by Weber \& Osborn (1969).

Estimation of $M_{r} . M_{\mathrm{r}}$ values of the purified enzymes were estimated by gel filtration on a Superose-6 HR 10/30 column using $20 \mathrm{~mm}-\mathrm{Tris} / \mathrm{HCl}$ buffer, $\mathrm{pH} 8.0$, containing $0.3 \mathrm{M}-\mathrm{NaCl}$. Horse spleen apoferritin $\left(M_{\mathrm{r}} 443000\right)$, bovine liver catalase $(232,000)$, sweet potato $\beta$-amylase (200000), rabbit muscle aldolase (158000), yeast alcohol dehydrogenase (150000), bovine albumin (66000), hen egg ovalbumin (45000) and whale myoglobin (17200) were used as reference proteins for gel filtration.

Rabbit muscle phosphorylase $b\left(M_{\mathrm{r}} 97400\right)$, bovine albumin (66000), hen egg ovalbumin (45000), pepsin (34700), chymotrypsinogen (25700), trypsin (23300), whale myoglobin (17200) and horse cytochrome $c(12400)$ were used as the standard marker proteins in SDS-PAGE (Weber \& Osborn, 1969).

Protein determination. Protein content was determined spectrophotometrically with an assumed absorption coefficient at $280 \mathrm{~nm}$ of 10.0 for a $1 \%(\mathrm{w} / \mathrm{v})$ solution.

Chemicals. All optically active amino acids used were of the L-configuration, unless otherwise stated. All marker proteins, peptides and amino acid derivatives used were purchased from Sigma. Tryptone, soytone and yeast extract were from Difco. All other chemicals were obtained as analytical grade from commercial sources. 


\section{RESULTS}

\section{Purification of aminopeptidases}

Two proteinase peaks and one aminopeptidase peak were eluted on DEAE-Sephadex column chromatography. Separation of proteinase from aminopeptidase activity was achieved by column chromatography on Mono-Q HR5/5. In a final purification step, a small portion of the active fraction was applied to a Superose- $6 \mathrm{HR} 10 / 30$ column and separated further into two peaks. The main peak, which contained $85 \%$ of the total activity remaining at the final purification step, was designated as aminopeptidase $A$ and the minor one as aminopeptidase $B$. Purified enzyme fractions of aminopeptidases A and B were obtained by reapplying each fraction to the gel filtration column, and these were used throughout the following experiments. A summary of the purification procedure is shown in Table 1. The enzyme activities of aminopeptidases A and B were purified 1720- and 1950-fold, respectively, giving specific activities of $53.1 \mathrm{U}(\mathrm{mg} \text { protein })^{-1}$ and $60.2 \mathrm{U}(\mathrm{mg} \text { protein })^{-1}$. The homogeneities of aminopeptidases A and B were determined by PAGE (Fig. 1 A, B). The enzyme activity of the bands of aminopeptidases $\mathrm{A}$ and $\mathrm{B}$ was confirmed by activity staining.

$$
M_{r} \text { values }
$$

The $M_{\mathrm{r}}$ values of aminopeptidases A and B were estimated to be 150000 and 110000 , respectively, by Superose- 6 gel filtration. When aminopeptidase A or B was dissociated in $0.1 \%$ SDS containing $1 \%(\mathrm{v} / \mathrm{v}) 2$-mercaptoethanol, and subjected to electrophoresis, single bands were observed after staining (Fig. 1 C, D). The migration of these bands corresponded to $M_{\mathrm{r}}$ values of 36000 for aminopeptidase A and 26000 for aminopeptidase B. The two native enzymes were thus each considered to be composed of four identical subunits.

\section{Effect of temperature and $\mathrm{pH}$ on the activities and stabilities of the enzymes}

Activity and stability at $\mathrm{pH} 8.5$ were measured at different temperatures from 25 to $60^{\circ} \mathrm{C}$. The apparent optimum temperature for activity was $40^{\circ} \mathrm{C}$ for both aminopeptidases $\mathrm{A}$ and $\mathrm{B}$. The enzymes were both stable below $40^{\circ} \mathrm{C}$ when incubated for $15 \mathrm{~min}$. The $\mathrm{pH}$ optima for aminopeptidases A and B were nearly the same (pH 9.3) when measured at $30^{\circ} \mathrm{C}$. The two enzymes were inactive on LNA at $\mathrm{pH}$ values below 5.5. The effect of $\mathrm{pH}$ on the stability of the enzymes at $30^{\circ} \mathrm{C}$ was determined by incubation in several buffers for $2 \mathrm{~h}$. The two aminopeptidases were most stable at their optimum $\mathrm{pH}$ of $9 \cdot 3$. Aminopeptidase A was slightly more stable than aminopeptidase $\mathrm{B}$ at $\mathrm{pH}$ values below 8 .

Table 1. Purification of the extracellular aminopeptidases from $B$. linens

\begin{tabular}{|c|c|c|c|c|c|}
\hline Purification step & $\begin{array}{l}\text { Volume } \\
(\mathrm{ml})\end{array}$ & $\begin{array}{l}\text { Activity } \\
\left(\mathrm{U} \mathrm{ml}^{-1}\right)\end{array}$ & $\begin{array}{l}\text { Specific activity } \\
\left(\mathrm{U} \mathrm{mg}^{-1}\right)\end{array}$ & $\begin{array}{l}\text { Yield } \\
(\%)\end{array}$ & $\begin{array}{l}\text { Purification } \\
\text { (-fold) }\end{array}$ \\
\hline Culture filtrate & 10000 & 0.0897 & 0.0308 & 100 & 1 \\
\hline $\begin{array}{l}\text { Ammonium sulphate } \\
\text { fractionation }\end{array}$ & 120 & $10 \cdot 1$ & 0.385 & 136 & $12 \cdot 5$ \\
\hline $\begin{array}{l}\text { DEAE-Sephadex A-50 } \\
\text { chromatography }\end{array}$ & 105 & 7.47 & $15 \cdot 3$ & 87.7 & 498 \\
\hline $\begin{array}{l}\text { DEAE-Trisacryl M } \\
\text { chromatography }\end{array}$ & 72 & 3.97 & $21 \cdot 3$ & $32 \cdot 0$ & 692 \\
\hline $\begin{array}{l}\text { Mono-Q HR5/5 } \\
\text { chromatography* }\end{array}$ & - & - & $48 \cdot 1$ & $(24 \cdot 7)^{*}$ & 1560 \\
\hline $\begin{array}{l}\text { Superose-6 HR 10/30 } \\
\text { gel filtration* }{ }^{*}\end{array}$ & & & & & \\
\hline $\begin{array}{l}\text { Aminopeptidase A } \\
\text { Aminopeptidase B }\end{array}$ & $\begin{array}{l}- \\
-\end{array}$ & - & $\begin{array}{l}53 \cdot 1 \\
60 \cdot 2\end{array}$ & $\begin{array}{l}(12 \cdot 0)^{*} \\
(2 \cdot 19)^{*}\end{array}$ & $\begin{array}{l}1720 \\
1950\end{array}$ \\
\hline
\end{tabular}

* Only a portion of sample was applied in these steps as columns are semipreparative size. Yields were calculated based on the application of a portion of sample to the column.

$\dagger$ The aminopeptidase fraction was separated into two fractions, aminopeptidase $A$ and $B$, in this step. 

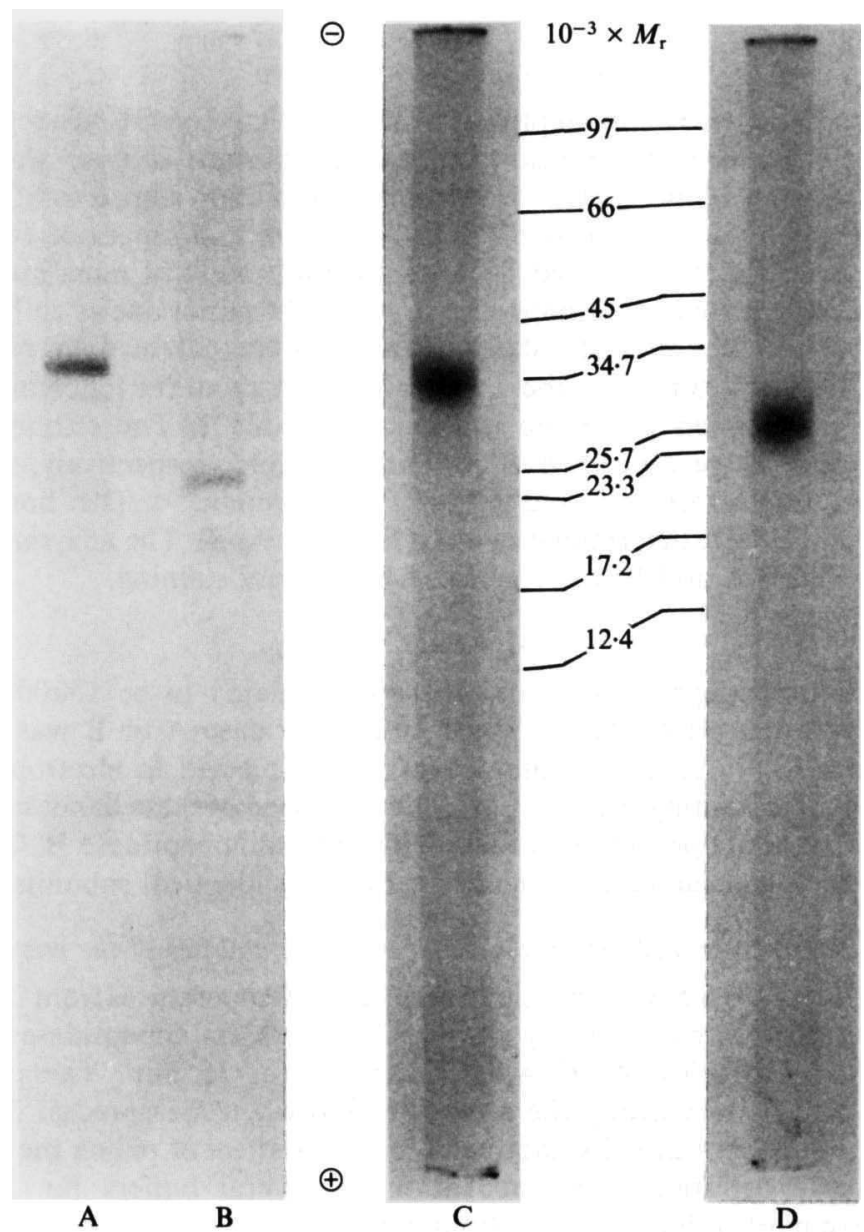

Fig. 1. Homogeneities of the purified aminopeptidase A (A) and aminopeptidase B (B) on polyacrylamide gel; C, D, aminopeptidase A (C) and aminopeptidase B (D) on SDS-polyacrylamide gel. All gels were stained with Coomassie brilliant blue R-250.

Effect of metal ions and EDTA on the enzymes

None of the metal ions tested enhanced the activities of the two enzymes; they were not affected by $\mathrm{Ba}^{2+}, \mathrm{Ca}^{2+}$ or $\mathrm{Mg}^{2+}$, but were strongly inhibited by $\mathrm{Cu}^{2+}, \mathrm{Mn}^{2+}, \mathrm{Zn}^{2+}, \mathrm{Hg}^{2+}$ and $\mathrm{Cd}^{2+}$ (Table 2). Both enzymes completely lost their activity when incubated with $0 \cdot 1 \mathrm{mM}$-EDTA. The EDTA-inactivated aminopeptidases $\mathrm{A}$ and $\mathrm{B}$ were reactivated by incubation with $\mathrm{Ca}^{2+}$, $\mathrm{Co}^{2+}, \mathrm{Mg}^{2+}, \mathrm{Zn}^{2+}$ or $\mathrm{Mn}^{2+}$ (Table 3).

\section{Analysis of $K_{m}$ and substrate specificity}

The $K_{\mathrm{m}}$ values of aminopeptidases A and B for LNA were $16 \cdot 1$ and $15 \cdot 2 \mathrm{mM}$, respectively. The $K_{\mathrm{m}}$ of aminopeptidase A for Leu-Arg and Leu-Leu was 5.25 and $85 \mathrm{mM}$, respectively.

Table 4 summarizes the initial rates of hydrolysis of peptides and amino acid derivatives by aminopeptidase A. The $K_{\mathrm{m}}$ values obtained for Leu-Arg, LNA and Leu-Leu indicate that the substrate concentrations for these three substrates, and probably for other peptides, are not 
Table 2. Effect of various metal ions on aminopeptidase $A$ and $B$ activities

Enzyme (17 milliunits of aminopeptidase A or B) was preincubated for $1 \mathrm{~h}$ at $30^{\circ} \mathrm{C}$ with the metal salt indicated. After incubation, the activity was measured by the standard assay. Enzyme activity in the absence of metal salts measured by the standard assay was defined as $100 \%$.

\begin{tabular}{lcc} 
Metal salt & \multicolumn{2}{c}{ Relative activity (\%) } \\
\cline { 2 - 3 }$(1 \mathrm{mM})$ & Aminopeptidase A & Aminopeptidase B \\
$\mathrm{BaCl}_{2}$ & $98 \cdot 6$ & $99 \cdot 4$ \\
$\mathrm{CaCl}_{2}$ & $96 \cdot 9$ & $93 \cdot 3$ \\
$\mathrm{MgCl}_{2}$ & $90 \cdot 4$ & $91 \cdot 3$ \\
$\mathrm{CoCl}_{2}$ & $32 \cdot 4$ & $32 \cdot 0$ \\
$\mathrm{AlCl}_{3}$ & $21 \cdot 1$ & $18 \cdot 1$ \\
$\mathrm{FeCl}_{2}$ & 14.8 & $16 \cdot 4$ \\
$\mathrm{CuCl}_{2}$ & $8 \cdot 4$ & $7 \cdot 5$ \\
$\mathrm{MnCl}_{2}$ & $5 \cdot 1$ & $5 \cdot 8$ \\
$\mathrm{ZnCl}_{2}$ & $1 \cdot 5$ & $1 \cdot 4$ \\
$\mathrm{HgCl}_{2}$ & $1 \cdot 2$ & $2 \cdot 1$ \\
$\mathrm{CdCl}_{2}$ & 0.6 & $1 \cdot 2$ \\
$\mathrm{SnCl}_{2}{ }^{*}$ & $9 \cdot 7$ & $11 \cdot 1$ \\
$\mathrm{NiCl}_{2}{ }^{*}$ & $2 \cdot 1$ & 3.4 \\
$\mathrm{PbCl}_{2}{ }^{*}$ & 0.6 & $1 \cdot 2$ \\
$\mathrm{None}$ & 100 & 100
\end{tabular}

* Precipitate was observed during the enzyme reaction.

Table 3. Reactivation of EDTA-inactivated aminopeptidases $A$ and $B$ by several metal ions

The native enzyme ( 17 milliunits of aminopeptidase $A$ or B) was incubated with $0 \cdot 1 \mathrm{mM}$-EDTA at $0{ }^{\circ} \mathrm{C}$ for $1 \mathrm{~h}$, then metal salt was added to a concentration of $0.1 \mathrm{mM}$. After incubation for $30 \mathrm{~min}$ at $0{ }^{\circ} \mathrm{C}$, the enzyme was assayed. The final concentrations of metal ion and EDTA in the standard assay were 0.04 $\mathrm{mm}$ and $0.004 \mathrm{mM}$, respectively. The activity of the native enzyme which was not treated by EDTA was measured in the absence of metal salts and is defined as $100 \%$.

\begin{tabular}{lcc} 
& \multicolumn{2}{c}{ Extent of reactivation (\%) } \\
\cline { 2 - 3 } Metal salt & Aminopeptidase A & Aminopeptidase B \\
$\mathrm{CaCl}_{2}$ & $99 \cdot 5$ & $98 \cdot 0$ \\
$\mathrm{CoCl}_{2}$ & $89 \cdot 3$ & $87 \cdot 1$ \\
$\mathrm{MgCl}_{2}$ & $47 \cdot 0$ & $36 \cdot 8$ \\
$\mathrm{ZnCl}_{2}$ & $36 \cdot 4$ & $26 \cdot 7$ \\
$\mathrm{MnCl}_{2}$ & $20 \cdot 5$ & $33 \cdot 2$ \\
None & 0 & 0
\end{tabular}

saturating. Therefore, the initial rates of hydrolysis of these peptides reflect both $K_{\mathrm{m}}$ and $V$ values. The following substrate specificities for aminopeptidase $A$ can be deduced: the substrates with an $\mathrm{N}$-terminal leucine were the most readily hydrolysed among the tested peptides; a strong specificity was observed with regard to the second amino acid, since in a series of dipeptides with $\mathrm{N}$-terminal leucine the rate of hydrolysis varied by a factor of 324 (relative activity of 3.4 for Leu-Gly and 1100 for Leu-Arg); not only dipeptides but also tripeptides and tetrapeptides were hydrolysed; an amino acid derivative which has an acidic amino acid (Glu- $p$ NA) is not a substrate for this enzyme. Peptides consisting of D-amino acids such as D-Leu-D-Leu were not hydrolysed by either of the two enzymes. Substrate specificities of the two enzymes were very similar to each other. 
Table 4. Substrate specificities of aminopeptidase $A$

To minimize experimental error, enzyme concentration (1.5-30 milliunits) and incubation time (5-180 $\mathrm{min}$ ) were varied depending on the susceptibility of each substrate.

\begin{tabular}{|c|c|c|c|}
\hline Substrate* & Relative activity $\dagger$ & Substrate* & Relative activity $\dagger$ \\
\hline Gly-Leu & $<0.1$ & Tyr-Leu & $28 \cdot 8$ \\
\hline -Phe & $<0.9$ & Phe-Ala & $<2.5$ \\
\hline Ala-Ala & $3 \cdot 6$ & -Leu & $4 \cdot 3$ \\
\hline -Pro & 3.6 & -Phe & $7 \cdot 9$ \\
\hline- Val & $6 \cdot 0$ & -Phe-Phe & $49 \cdot 1$ \\
\hline -Leu & $5 \cdot 0$ & -Phe-Phe-Phe* & 21.8 \\
\hline -Phe & $11 \cdot 8$ & Lys-Ile & $2 \cdot 2$ \\
\hline -Lys & 11.0 & -Phe & 5.5 \\
\hline Val-Ala & 1.8 & His-Ala & $2 \cdot 6$ \\
\hline -Pro & $<2.9$ & -Leu & $19 \cdot 8$ \\
\hline -Phe & $11 \cdot 2$ & -Lys & $60 \cdot 0$ \\
\hline Met-Gly & 0.8 & -Phe & $25 \cdot 0$ \\
\hline -Pro & $<0.4$ & Arg-Leu & $5 \cdot 5$ \\
\hline Leu-NH ${ }_{2}$ & $26 \cdot 0$ & Try-Ala & 3.7 \\
\hline -Ser & $42 \cdot 7$ & & \\
\hline -Pro & 3.7 & Pro-Gly & $0 \cdot 3$ \\
\hline -Gly & 3.4 & -Met & $15 \cdot 2$ \\
\hline- Ala & 52.9 & -Leu & 0.9 \\
\hline- Val & 91.8 & $-\mathrm{Tyr}$ & 4.9 \\
\hline- Met & (435) & -Phe & $4 \cdot 5$ \\
\hline -Ile & $42 \cdot 5$ & - Try & $4 \cdot 6$ \\
\hline -Leu & (100) & & \\
\hline- Tyr & (216) & Glu-pNA & $<0.02$ \\
\hline -Phe & (182) & Ala-pNA & $10 \cdot 4$ \\
\hline$-\operatorname{Arg}$ & (1364) & Leu-pNA & $745 \quad(764)$ \\
\hline- Try & (239) & Lys-pNA & 39.8 \\
\hline -Leu-Leu & 131 & & \\
\hline D-Leu-D-Leu & $<0.1(<0.1)$ & & \\
\hline D-Leu-L-Leu & $<0.1(<0.1)$ & & \\
\hline L-Leu-D-Leu & $<0.1(<0.1)$ & & \\
\hline
\end{tabular}

* All amino acids were in the L-configuration, except where indicated. Concentration of substrate was $1 \mathrm{~mm}$ except for tetraphenylalanine (about $0.4 \mathrm{mM}$ ).

† Rate of hydrolysis relative to that of Leu-Leu, for which $6.7 \%$ of the substrate was hydrolysed after incubation with aminopeptidase A or B ( 3 milliunits) at $30^{\circ} \mathrm{C}$ for $10 \mathrm{~min}$. Figures in parentheses are for aminopeptidase $\mathrm{B}$.

\section{DISCUSSION}

The aminopeptidases investigated in this study were purified from the culture filtrate of $B$. linens $\mathrm{F}$. A previous study of peptide hydrolase of the same species by a zymogram technique suggested the presence of more than one enzyme (Sørhaug, 1981; Torgersen \& Sørhaug, 1978). This has been confirmed by our isolation of aminopeptidases A and B; the former showed $85 \%$ of the total activity remaining at the final purification step.

The physical and chemical properties of aminopeptidases A and B were very similar. The two enzymes showed the same apparent temperature optimum of $40{ }^{\circ} \mathrm{C}$ and the same $\mathrm{pH}$ optimum of $9 \cdot 3$, although a slight difference was found in $\mathrm{pH}$ stability, aminopeptidase $\mathrm{A}$ being slightly more stable at acidic $\mathrm{pH}$ than aminopeptidase B. $K_{\mathrm{m}}$ values for LNA hydrolysis by the two enzymes were similar: $16.1 \mathrm{~mm}$ for aminopeptidase A and $15.2 \mathrm{~mm}$ for aminopeptidase $B$. The two enzymes are considered to be metalloenzymes since they were inactivated by treatment with EDTA and reactivated by incubation with various divalent metal ions. Evidence that each enzyme consists of four identical subunits was obtained from SDS-PAGE. In contrast, Foissy $(1978 b)$ reported the aminopeptidase of $B$. linens to be a dimer consisting of identical monomers of $M_{\mathrm{r}} 48000$. The only prominent difference found between aminopeptidases A and B was in their estimated $M_{\mathrm{r}}, 150000$ for native aminopeptidase A and 110000 for aminopeptidase B. 
The two enzymes were so similar in their properties that they may be regarded as isoenzymes of group 1 (genetically independent proteins) or group $4 \mathrm{~b}$ (conjugated or derived proteins, proteins derived from single polypeptide chains) (IUPAC-IUB CBN, 1977). Multiple forms of peptidases have also been reported from other organisms (Hasegawa et al., 1985; Kim \& Brophy, 1976; Rabier \& Desmazeaud, 1973). It is possible that the difference in $M_{\mathrm{r}}$ between aminopeptidases A and B is due to different carbohydrate contents, as reported for peptidases $F$ and $S$ from rat brush border membrane peptidase (Kim \& Brophy, 1976). It is also possible that aminopeptidase A was converted to aminopeptidase B by specific proteolytic hydrolysis, although the incubation of aminopeptidase A with proteinase isolated from the same strain failed to produce aminopeptidase B. Until further information is available the term 'multiple forms of the enzyme' should be used.

The effect of $\mathrm{Co}^{2+}$ on the activity of aminopeptidases A and B is not entirely consistent with that on other similar metalloenzymes. Activation of native enzyme by incubation with $\mathrm{Co}^{2+}$ was observed in the enzyme purified from B. linens (Foissy, 1978a), Streptococcus cremoris (Hwang et al., 1981), Streptococcus faecalis (White \& Clewell, 1986) and Bacillus stearothermophilus (Zuber \& Roncari, 1967). More than $100 \%$ of the original activity was observed with enzyme renatured by incubation with $\mathrm{Co}^{2+}$ for the enzyme purified from Thermus aquaticus (Minagawa et al., 1988) and Escherichia coli (Yoshimoto et al., 1988). However, we observed slight inhibition of native enzyme and only partial renaturation of EDTA-denatured enzyme by incubation with $\mathrm{Co}^{2+}$ for aminopeptidases $\mathbf{A}$ and $\mathbf{B}$.

The purified aminopeptidases A and B hydrolysed a variety of substrates, showing a specificity for N-terminal leucine. Their substrate specificity differed from that of the aminopeptidase purified by Foissy (1978b). A marked difference was observed in the ratio of the reaction velocity for L-leucinamide and LNA: aminopeptidase A had a ratio of 29:1 with the respective substrates, while the enzyme reported by Foissy (1978b) had a ratio of $1: 6$. The specificity of the purified aminopeptidase A was not restricted to dipeptides; tripeptide and tetrapeptide substrates were also hydrolysed. Proline iminopeptidase activity (Yoshimoto \& Tsuru, 1985) was also confirmed, as the enzyme hydrolysed L-prolyl-L-methionine and related substrates. This broad substrate specificity of the enzyme, which hydrolyses peptides containing $\mathrm{N}$-terminal hydrophobic, aromatic and basic amino acids as well as proline, seems ideal for the purpose of accelerated ripening of cheese (Law \& Wigmore, 1983).

The aminopeptidase I of $E$. coli is sensitive to the monovalent ion concentration (Vogt, 1970), but the enzyme activities and stabilities of aminopeptidases $A$ and $B$ measured in $50 \mathrm{~mm}$ Tris/ $\mathrm{HCl}$ buffer $\mathrm{pH} 8.5$ were not affected by $\mathrm{NaCl}$ or $\mathrm{KCl}$ concentration up to $2 \mathrm{M}$. No metal ion was required for the enzyme activity of the aminopeptidases isolated from $B$. linens $F$ while the presence of $\mathrm{Mn}^{2+}$ and $\mathrm{Co}^{2+}$ was essential for the activity of aminopeptidase of Clostridium histolyticum (EC 3.4.11.13, Kessler \& Yaron, 1973). From the data described here, aminopeptidases A and B appear to belong to the same classification as Aeromonas proteolytica aminopeptidase [ $\alpha$-aminoacyl-peptide hydrolase (Aeromonas proteolytica), EC 3.4.11.10] (IUB, 1984), although some differences between the aminopeptidases isolated from $A$.proteolytica and $B$. linens $F$ were observed in the substrate specificity for L-leucinamide and LNA, and in the rate of reactivation by metal ions (Prescott \& Wilkes, 1966; Wilkes et al., 1973).

This work was supported by Japan International Cooperation Agency. We thank Mr A. J. Cliff (AFRC Institute of Food Research, Reading Laboratory) for his kind support of the experiments, Dr C. H. Tzeng (Chr. Hansen's Laboratory Co.) for kindly providing the strain and Dr A. Hosono (Shinshuu University) for useful discussion.

\section{REFERENCES}

Doi, E., Shibata, D. \& Matoba, T. (1981). Modified colorimetric ninhydrin methods for peptidase assay. Analytical Biochemistry 118, 173-184.

Forssy, H. (1978a). Aminopeptidase from Brevibacterium linens. Zeitschrift für Lebensmittel-Untersuchung und Forschung 166, 164-166.
FoISSY, H. (1978b). Some properties of aminopeptidase from Brevibacterium linens. FEMS Microbiology Letters 3, 207-210.

FoIssy, H. (1978c). Aminopeptidase from Brevibacterium linens, production and purification. Milchwissenschaft 33, 221-223. 
Folin, O. \& Ciocalteu, V. (1927). On tyrosine and tryptophane determinations in proteins. Journal of Biological Chemistry 73, 627-650.

Hasegawa, Y., Kodama, O. \& Akatsuka, T. (1985). Solubilization and some properties of membranebound aminopeptidases of hog small intestinal mucosa. Nippon Nogeikagaku Kaishi 59, 397-403.

Hwang, I. K., Kaminogawa, S. \& Yamauchi, K. (1981). Purification and properties of a dipeptidase from Streptococcus cremoris. Agricultural and Biological Chemistry 45, 159-165.

IUB (1984), Enzyme Nomenclature 1984. Orlando: Academic Press.

IUPAC-IUB CBN (1977). Nomenclature of multiple forms of enzymes, recommendations (1976). Journal of Biological Chemistry 252, 5939-5941.

KeSSLER, E. \& YARON, A. (1973). A novel aminopeptidase from Clostridium histolyticum. Biochemical and Biophysical Research Communications 50, 405-412.

KIM, Y. S. \& BROPHY, E. J. (1976). Rat intestinal brush border membrane peptidases. Journal of Biological Chemistry 251, 3199-3211.

LAW, B. A. (1984). Flavour development in cheeses. In Advances in the Microbiology and Biochemistry of Cheese and Fermented Milk, pp. 187-208. Edited by F. L. Davies \& B. A. Law. London: Elsevier Applied Science Publishers.

LAW, B. A. \& Wigmore A. S. (1983). Accelerated ripening of cheddar cheese with a commercial proteinase and intraceliular enzymes from starter streptococci. Journal of Dairy Research 50, 519-525.

Minagawa, E., Kaminogawa, S., Matsuzawa, H., OHTA, T. \& YAMAUCHI, K. (1988). Isolation and characterization of a thermostable aminopeptidase from Thermus aquaticus YT-1. Agricultural and Biological Chemistry 52, 1755-1763.

ORnSTEIN, L. (1964). Disk electrophoresis. 1. Background and theory. Annals of the New York Academy of Sciences 121, 321-349.
Prescott, J. M. \& Wilkes, S. H. (1966). Aeromonas aminopeptidase, purification and some general properties. Archives of Biochemistry and Biophysics 117, 328-336.

RABIER, D. \& Desmazeaud, M. J. (1973). Inventory of different intracellular peptidase activities of Streptococcus thermophilus. Biochimie 55, 389-404.

SørHaug, T. (1981). Comparison of peptide hydrolases from six strains of Brevibacterium linens. Milchwissenschaft 36, 137-139.

Torgersen, H. \& Sørhaug, T. (1978). Peptide hydrolases of Brevibacterium linens. FEMS Microbiology Letters 4, 151-153.

VoGT, V. M. (1970). Purification and properties of an aminopeptidase from Escherichia coli. Journal of Biological Chemistry 245, 4760-4769.

WEBER, K \& OSBORN, M. (1969). The reliability of molecular weight determinations by dodecyl sulfatepolyacrylamide gel electrophoresis. Journal of Biological Chemistry 244, 4406-4412.

White, B. A. \& Clewell, D. B. (1986). Identification and partial purification of a dipeptidyl aminopeptidase from Streptococcus faecalis. Journal of General Microbiology 132, 1269-1276.

Wilkes, S. H., Bayliss, M. E. \& Prescott, J. M. (1973). Specificity of Aeromonas aminopeptidase toward oligopeptides and polypeptides. European Journal of Biochemistry 34, 459-466.

Yoshimoto, T. \& Tsuru, D. (1985). Proline iminopeptidase from Bacillus coagulans. Journal of Biochemistry 97, 1477-1485.

Yoshimoto, T., Tamesa, Y., Gushi, K., Murayama, N. \& Tsuru, D. (1988). An aminopeptidase $\mathbf{N}$ from Escherichia coli HB101. Agricultural and Biological Chemistry 52, 217-225.

Zuber, H. \& Roncari, G. (1967). Thermophilic and mesophilic aminopeptidases from Bacillus stearothermophilus. Angewandte Chemie-International English Edition 6, 880-881. 